\title{
Processed cheese foods with added whey protein concentrates
}

\author{
VK Gupta*, H Reuter \\ Institut für Verfahrenstechnik der Bundesanstalt für Milchforschung, Kiel, Germany
}

(Received 10 June 1991; accepted 15 November 1991)

\begin{abstract}
Summary - The technique for the manufacture of processed cheese foods has been standardized with $20 \%$ of their cheese solids replaced by whey protein concentrates (WPC). Among the different emulsifiers tested (a combination of trisodium citrate and disodium phosphate and trisodium citrate alone) only trisodium citrate was able to produce a smooth texture. Trisodium citrate at $2.5 \%$ and with a moisture content of $45.2 \%$ resulted in processed cheese foods with the best sensory characteristics (out of a total of 7 , the scores were as follows: flavour, 5.5 ; consistency, 6 ; appearance, 5.8; overall acceptability, 5.6). WPC with a high UF concentration (26.1\% TS) and low calcium content $(0.7 \%$ on dry basis) were found to be the most suitable for incorporation in processed cheese foods. Diafiltration of WPC had a negative effect as regards suitability for the product. The standardized technique for processed cheese manufacture is: take a mixture of $25 \%$ 6.5-7.5-month-old and 55\% 2-3-month-old grated cheddar cheese), WPC equivalent to $20 \%$ of cheese solids, dry salt and water; heat the contents with thorough stirring by indirect steam heating. At a temperature of about $49{ }^{\circ} \mathrm{C}$, sprinkle $2.5 \%$ dry trisodium citrate and continue heating until the temperature reaches $82^{\circ} \mathrm{C}$, and maintain this temperature for 3-4 min.
\end{abstract}

processed cheese foods / whey protein concentrate addition / emulsifying salts

Résumé - Fabrication de fromage fondu avec ajout de concentrés de protéines de lactosérum. Un procédé de fabrication de fromage fondu basé sur le remplacement de $20 \%$ de la matière sèche fromagère par un concentré de protéines de lactosérum (CPL) a été développé. Parmi les différents émulsifiants testés (citrate trisodique seul ou citrate trisodique + phosphate disodique), seul le citrate trisodique était à même de donner une texture lisse au produit. Les meilleures caractéristiques sensorielles (sur 7, les scores étant pour la flaveur : 5,5, la consistance: 6 , l'apparence : 5,8 , l'acceptabilité générale : 5,6 ) étaient obtenues avec $2,5 \%$ de citrate trisodique et une teneur en eau de $45,2 \%$. Une forte concentration des CPL (26, $1 \%$ de la matière sèche) et une faible teneur en calcium $(0,7 \%$ de la matière sèche) facilitaient leur incorporation dans le mélange de fonte. Par contre, la diafiltration conduisait à un effet inverse. Le procédé de fabrication développé était le suivant : addition dans le pétrin de fromage cheddar rapé (mélange de 25\% de fromage âgé de 6,5-7,5 mois, et $55 \%$ de fromage âgé de 2-3 mois), d'une quantité de CPL équivalente à $20 \%$ de la matière sèche du fromage, de sel sec et d'eau; chauffage du contenu par la paroi avec agitation régulière. Lorsque la température atteignait $49{ }^{\circ} \mathrm{C}$, saupoudrage de citrate trisodique sec à $2,5 \%$; poursuite du chauffage jusqu'à $82^{\circ} \mathrm{C}$ et maintien de cette température pendant 3 à 4 min.

fromage fondu / concentré de protéine de lactosérum / sels émulsifiants

\footnotetext{
* Present address: Dairy Technology Division, National Dairy Research Institute, Karnal-132 001,
} India. 


\section{INTRODUCTION}

A fairly large amount of processed cheese foods is prepared in the USA, Russia and many East European countries, but much work still has to be done on standardizing this product. There is very little information available on processed cheese foods with added whey protein concentrates (Georgakis, 1975; Kairyukshtene et al, 1978).

Whey has long been known to contain proteins of high nutritional value, but their use in human nutrition has been complicated by the high lactose and low protein content (Forsum, 1975). Ultrafiltration (UF) technology developed over the last 2 decades has now made possible the production at a relatively economical price of whey protein concentrates (WPC) which are low in lactose. With this new technology, it has also become possible to produce WPC with different physicochemical and functional properties for applications in different food systems.

Processed cheese is a complex system composed of protein, fat, mineral salts and other ingredients. Its properties are affected by many variables such as composition and nature of the initial natural cheese, the nature and amount of the emulsifying agents, the manufacturing procedure and additional factors (Caric et al, 1985). The emulsifier plays a very important role in producing desirable body and texture characteristics, and melting and slicing properties in the finished cheese products. Three major categories of extensively employed emulsifying salts are: citrates, monophosphates and polyphosphates (Kosikowski, 1982; Shimp, 1985).

In the present investigation, an attempt has been made to add WPC in the formulation of processed cheese foods and to standardize their manufacturing process.

\section{MATERIALS AND METHODS}

\section{Manufacture of WPC}

Different types of WPC (table I) were prepared by ultrafiltration (UF) of Tilsit cheese whey on an UF module with a hollow fiber membrane (Romicon, polysulfone membrane type pM 50, fiber inside diameter $1.1 \mathrm{~mm}$, effective membrane area $2.5 \mathrm{~m}^{2}$, molecular weight cutoff, 50000 ) by varying; a) preheating treatment of whey (holding period, $30 \mathrm{~min}$ ); b), UF temperature; c), level of UF concentration; and d), diafiltration treatment as described earlier (Gupta and Reuter, 1987). These WPC were put in polythene bags and kept at $-20^{\circ} \mathrm{C}$ till used.

\section{Manufacture of processed cheese/ processed cheese foods}

A blend of $25 \%$ old Cheddar cheese (6.5-7.5 months old) and $75 \%$ young Cheddar cheese (2-3 months old) was used for processed cheese manufacture. For processed cheese foods, part of the young cheddar cheese solids were replaced by WPC solids. The amount of WPC for replacement of Cheddar cheese was calculated as follows:

amount of WPC $(\mathrm{g}): \frac{a \times b}{c}$

where $a=\%$ total solids of young Cheddar cheese; $b=$ amount of young cheese to be replaced $(g) ; c=\%$ total solids of WPC.

Young and old Cheddar cheeses were kept at room temperature overnight, cleaned, quartered and grated. The calculated amount of Cheddar cheese, WPC, salt and water for preparing $1 \mathrm{~kg}$ product were added in a $2.5-1$ semi-spherical stainless steel kettle. The water added also included the subsequent water loss ( $175 \mathrm{ml}$ ) due to evaporation during heat processing of cheese. The contents in the kettle were heated with continuous stirring and scraping of the surface. As the temperature approached $49^{\circ} \mathrm{C}$, the emulsifying salt either after dissolving in water or in dry form was slowly added and thoroughly mixed. 
Table I. Different whey protein concentrates used in processed cheese foods.

Caractéristiques des concentrés de protéines de lactosérum utilisés dans les fromages fondus.

\begin{tabular}{|c|c|c|c|c|c|c|c|c|c|c|}
\hline $\begin{array}{l}\text { Temperature } \\
\text { pre- } \\
\text { heating }\end{array}$ & $\frac{\left({ }^{\circ} \mathrm{C}\right)}{U F}$ & $\begin{array}{c}\text { Diafil- } \\
\text { tration }\end{array}$ & $\begin{array}{l}T S \\
\text { (\%) }\end{array}$ & $\begin{array}{l}\text { Protein/ } \\
\text { TS (\%) }\end{array}$ & $\begin{array}{l}\text { Fat/TS } \\
\text { (\%) }\end{array}$ & $\begin{array}{l}\text { Ash/TS } \\
\text { (\%) }\end{array}$ & $\begin{array}{l}\mathrm{Ca} T \mathrm{TS} \\
\text { (\%) }\end{array}$ & $\begin{array}{l}\text { Lactose/ } \\
\text { TS (\%) }\end{array}$ & $p H$ & Type of WPC \\
\hline $68-72$ & 50 & No & 18.3 & 63.8 & 2.2 & 6.1 & 1.3 & 29.5 & 6.5 & WPC (18.3) \\
\hline 40 & 50 & No & 19.5 & 67.9 & 2.1 & 4.5 & 0.6 & 27.2 & 6.5 & WPC (19.5) \\
\hline $68-72$ & 60 & No & 20.1 & 65.1 & 2.5 & 6.8 & 1.4 & 25.4 & 6.5 & WPC (20.1) \\
\hline 45 & 45 & No & 25.1 & 74.9 & 2.5 & 4.1 & 0.8 & 22.5 & 6.5 & WPC (25.1) \\
\hline 40 & 50 & No & 26.1 & 76.3 & 2.4 & 4.0 & 0.7 & 22.4 & 6.5 & WPC (26.1) \\
\hline 25 & 25 & Yes & 13.0 & 72.6 & 2.4 & 3.9 & 0.6 & 20.1 & 6.7 & WPCD (13.0) \\
\hline $68-72$ & 60 & Yes & 16.5 & 74.1 & 2.5 & 5.8 & 1.7 & 15.2 & 6.7 & WPCD (16.5) \\
\hline $68-72$ & 60 & Yes & 19.7 & 78.9 & 2.6 & 5.7 & 1.8 & 12.2 & 6.7 & WPCD (19.7) \\
\hline $68-72$ & 50 & Yes & 23.6 & 82.6 & 2.7 & 5.3 & 1.6 & 9.5 & 6.7 & WPCD (23.6) \\
\hline
\end{tabular}


Heating was continued to $82^{\circ} \mathrm{C}$, and the temperature maintained for 3-4 min. The entire processing period lasted $15 \mathrm{~min}$. The hot product was then immediately poured into plastic cups (Bellaplast, Art No 810) which were secured with airtight lids. Cups were maintained overnight at $18^{\circ} \mathrm{C}$ and then moved to cold store maintained at $6{ }^{\circ} \mathrm{C}$.

\section{Chemical analysis}

WPC were analysed for their chemical composition as follows:

- total solids by gravimetric procedure;

- protein by the Kjeldahl method (AOAC, 1970), protein factor 6.38 ;

- fat by the Gerber method;

- ash by AOAC (AOAC, 1970);

- calcium and lactose using a Technicon Autoanalyser;

- pH using a pH meter (E 5000, Metrohm, Switzerland).

Cheddar cheese, processed cheese and processed cheese foods were analysed for moisture by gravimetric method.

\section{Sensory evaluation of processed cheese foods/processed cheeses}

Products were evaluated for flavour, consistency, appearance and overall acceptability by a 7member panel. The cheese samples were kept at $18{ }^{\circ} \mathrm{C}$ overnight preceding sensory evaluation. The order of testing was randomized. To assist the judges in describing defects, the scores sheet included a list of suggested flavour, consistency and appearance defects. The judges were asked to give an overall score ranging between $1-7$, where $7=$ excellent, $6=$ very good, $5=$ good, $4=$ fair, $3=$ poor, $2=$ very poor and $1=$ extremely poor.

\section{Statistical analysis}

The data were analysed, wherever necessary, for 2-way analysis of variance with interaction and 1-way analysis of variance without interaction as per the procedure of Snedecor and Cochran (1967). Critical difference was also calculated from the $t$-value.

\section{RESULTS}

\section{Effect of different emulsifying salts}

Processed cheese foods (43-44\% moisture) were prepared by replacing $7-20 \%$ of young cheese solids with WPC solids. During heat processing, there was no free fat release as was otherwise the case when no WPC was added. This indicated sufficient emulsification of fat even with $7 \%$ WPC. Flavour and appearance scores of the final food were on average 5 , but the texture was chalky and sandy, as a result of which the consistency score was below 4 and the total acceptance score on average 4. The use of diafiltered WPC (WPCD, 23.6) with lactose/TS as low as $9.5 \%$ did not prevent the sandiness in the processed cheese foods, suggesting that lactose was not responsible for the defective texture.

Emulsifying salts (Joha: S-8, 1.2\% and S-10, $0.8 \%$ ), which are widely utilized in Germany, when used at the $2 \%$ level did not improve the consistency of the processed cheese foods with added WPC. Trisodium citrate and disodium phosphate emulsifiers added in equal proportion at $2.0,2.5$ and $3.0 \%$ levels also failed to improve the texture of cheese foods. The sandiness appeared in all processed cheese food samples even with a low $5 \%$ WPC solids.

Other measures such as addition of WPC $0.5 \mathrm{~h}$ before heat processing, just before processing or during heat processing had no effect on preventing sandy or chalky texture in cheese foods. An attempt to manufacture processed cheese foods in 
a Stephan Universal Machine, employing a high-speed cutting device ( $3000 \mathrm{rpm}$ ) and direct steam injection, succeeded in giving a smooth textured product, but only under conditions of more than $55 \%$ moisture. At that high moisture level, the cheese food was very weak in body and unacceptable to the judges.

Lastly, an attempt was made using trisodium citrate alone as emulsifier, as is done in India. This emulsifier when used at the $3 \%$ level prevented the development of a sandy texture in the cheese foods even when up to $25 \%$ cheese solids were replaced with WPC solids (table III). The stage at which WPC was added, as mentioned earlier, did not affect the quality of the final product.

\section{Effect of different WPC}

Table II shows the effect of different WPC replacing $10 \%$ cheese solids on the senso- ry scores of processed cheese foods. Different WPC affected the flavour and consistency scores of processed cheese foods highly significantly $(P<0.01)$. Amongst the different WPC used, WPCD (16.5) imparted a significantly better flavour score (CD $=0.253$ ) to the final product, while WPC (18.3) and WPC (26.1) resulted in significantly better consistency scores ( $D=$ 0.335 ) compared to WPCD (13.0). For a higher level of WPC incorporation, a higher UF concentration was necessary to bring the moisture content to within acceptable upper limits in processed cheese foods. To avoid extra moisture, salts and emulsifying salts were added in dry form, and this did not affect the sensory quality of the final product.

The addition of diafiltered WPC tended to have a negative effect on the consistency of processed cheese foods. The effect was more prominent at higher levels (15$25 \%$ ) of WPC addition (table III). When WPCD (23.6) and WPC (26.1) were com-

Table II. Average sensory scores of processed cheese foods with $10 \%$ cheese solids replaced with different WPC.

Influence du remplacement de $10 \%$ de la matière sèche fromagère par différents CPL sur les caractéristiques sensorielles des fromages fondus.

\begin{tabular}{lcccc}
$\begin{array}{l}\text { Characteristics } \\
\text { of processed } \\
\text { cheese foods }\end{array}$ & WPC (18.3) & WPC (26.1) & WPCD (13.0) & WPCD (16.5) \\
\cline { 2 - 5 } & 43.5 & 44.9 & 45.2 & 45.3 \\
\hline Moisture (\%) & 4.9 & 4.9 & 5.1 & 5.4 \\
Flavour & 5.9 & 5.8 & 5.2 & 5.6 \\
Consistency & 5.8 & 5.9 & 6.0 & 5.9 \\
Appearance & 5.8 & 5.8 & 5.4 & 5.6 \\
$\begin{array}{l}\text { Overall } \\
\text { acceptability }\end{array}$ & & & & \\
\hline
\end{tabular}


Table III. Effect of diafiltered WPC on the average sensory scores of processed cheese foods. Effet de la diafiltration des CPL sur les caractéristiques sensorielles des fromages fondus.

\begin{tabular}{lrrrrrr}
\hline $\begin{array}{l}\text { Characteristics } \\
\text { of processed } \\
\text { cheese foods }\end{array}$ & $15 \%$ & $20 \%$ & $22.5 \%$ & $20 \%$ & $22.5 \%$ & $25 \%$ \\
\hline Moisture (\%) & 45.1 & 46.1 & 47.6 & 47.2 & 46.9 & 47.4 \\
Flavour & 5.8 & 4.5 & 3.2 & 6.0 & 6.0 & 5.8 \\
Consistency & 6.0 & 3.5 & 2.5 & 5.5 & 5.1 & 4.5 \\
Appearance & 6.0 & 5.8 & 5.1 & 6.0 & 5.2 & 5.0 \\
$\begin{array}{l}\text { Overall } \\
\text { acceptability }\end{array}$ & 6.0 & 4.1 & 3.2 & 5.8 & 5.5 & 5.1 \\
\hline
\end{tabular}

pared at 20 and $22.5 \%$ levels of addition in processed cheese foods, their flavour, consistency and overall acceptability scores were observed to be affected highly significantly $(P<0.01)$ with the type and levels of WPC addition. The higher level and diafiltration of WPC showed substantial adverse effects on the sensory quality of processed cheese foods.

\section{Effect of different moisture content}

Figure 1 illustrates the consistency scores of processed cheese foods with different moisture content when prepared with $3 \%$ trisodium citrate emulsifier and a varying amount of cheese solids replacement with WPC. It was observed that for better consistency (score, 5.7-6.0), the control sample had to have $41.4 \%$ moisture, whereas for the same good consistency the moisture content in processed cheese foods had to be increased proportionally with the increase of WPC addition. With 10,15 and $20 \%$ cheese solids replacement with
WPC, processed cheese foods scored $5.7-6.0$ in the vicinity of $44.9,45.9$ and $46.7 \%$ moisture content respectively. A higher moisture level than this resulted in a softer product while a lower moisture level made the body of the product harder and brittle.

\section{Effect of different levels of trisodium citrate}

In order to determine the optimum level of trisodium citrate, processed cheese foods were prepared with $1.5,2.0,2.5$ and $3.0 \%$ trisodium citrate. The amount of trisodium citrate added affected all the sensory indices of processed cheese foods (table IV) highly significantly $(P<0.01)$. Processed cheese foods with 2.5 and $3.0 \%$ trisodium citrate were judged to be much better in consistency, appearance and overall acceptability than with 1.5 and $2.0 \%$ trisodium citrate. On a flavour score basis, the product with $2.5 \%$ trisodium citrate was judged to be best. It was observed that at 


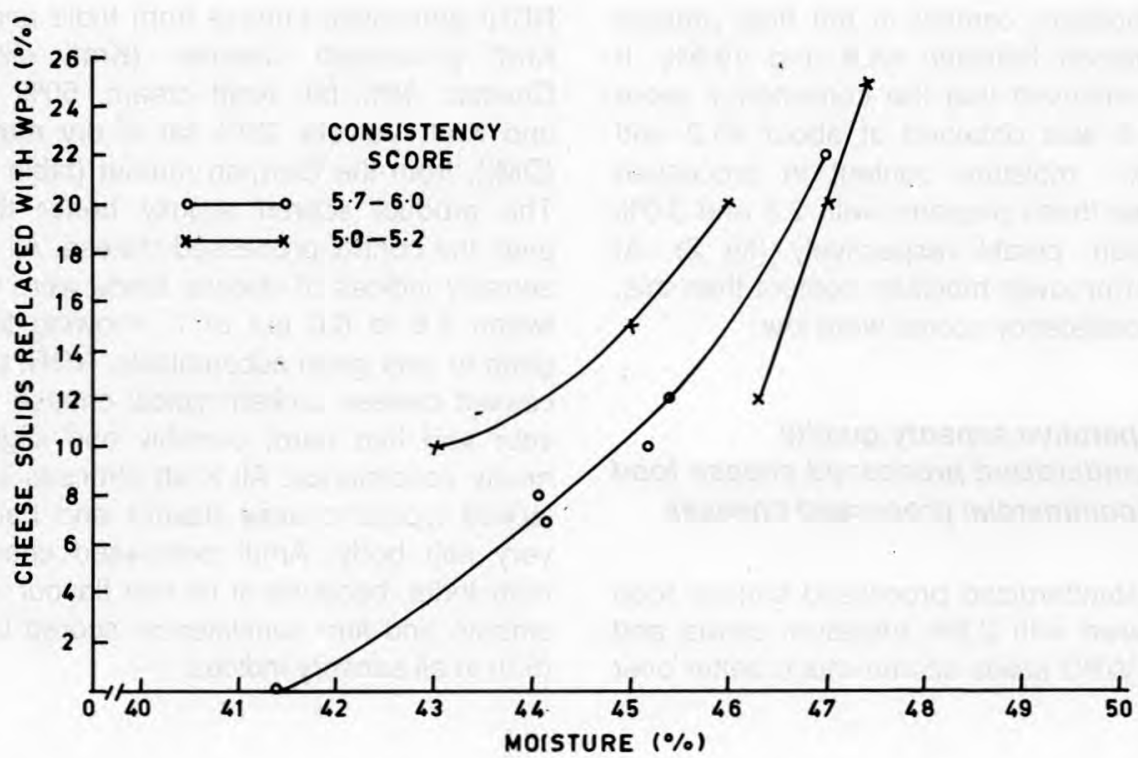

Fig 1. Consistency score of processed cheese foods as affected by different amounts of WPC and moisture.

Consistence des fromages fondus suivant l'apport de CPL et l'humidité.

Table IV. Effect of trisodium citrate level on the average sensory scores of processed cheese foods. Effet du taux de citrate trisodique sur les caractéristiques sensorielles des fromages fondus.

\begin{tabular}{|c|c|c|c|c|}
\hline Characteristics & & Trisoc & te $(\%)$ & \\
\hline cheese foods & 1.5 & 2.0 & 2.5 & 3.0 \\
\hline Moisture (\%) & 44.0 & 44.5 & 44.6 & 45.3 \\
\hline Flavour & 4.8 & 4.8 & 5.3 & 4.9 \\
\hline Consistenčy & 3.1 & 4.2 & 5.2 & 5.1 \\
\hline Appearance & 4.1 & 4.3 & 5.9 & 5.8 \\
\hline Overall acceptability & 4.1 & 4.2 & 5.4 & 5.1 \\
\hline
\end{tabular}

1.5 and $2 \%$ level of trisodium citrate, the product was mostly sandy. At a $2.5 \%$ level of trisodium citrate, the product was smooth in consistency and was almost comparable to cheese foods with $3.0 \%$ trisodium citrate.

\section{Standardized processed cheese foods}

A number of processed cheese foods were prepared by replacing $20 \%$ cheese solids with WPC (26.1). Trisodium citrate in dry form was added at 2.5 and $3.0 \%$ level and 
the moisture content in the final product maintained between 41.8 and $49.5 \%$. It was observed that the consistency score of $\approx 6$ was obtained at about 45.2 and $46.5 \%$ moisture content in processed cheese foods prepared with 2.5 and $3.0 \%$ trisodium citrate respectively (fig 2). At higher or lower moisture content than this, the consistency scores were low.

\section{Comparative sensory quality of standardized processed cheese food with commercial processed cheeses}

The standardized processed cheese food prepared with $2.5 \%$ trisodium citrate and $20 \%$ WPC solids scored much better over
NDRI processed cheese from India and 3 Kraft processed cheeses (Kraft sliced Chester, $45 \%$ fat; Kraft cream, 50\% fat, and Kraft Velveta, $20 \%$ fat in dry matter (DM)), from the German market (table V). The product scored slightly better than even the control processed cheese. All the sensory indices of cheese foods were between 5.5 to 6.0 out of 7 , showing their good to very good acceptability. NDRI processed cheese lacked typical cheese flavour and had hard, crumbly and slightly mealy consistency. All Kraft cheeses also lacked typical cheese flavour and had a very soft body. Amul processed cheese from India, because of its rich flavour and smooth and firm consistency, scored best (6.0) in all sensory indices.

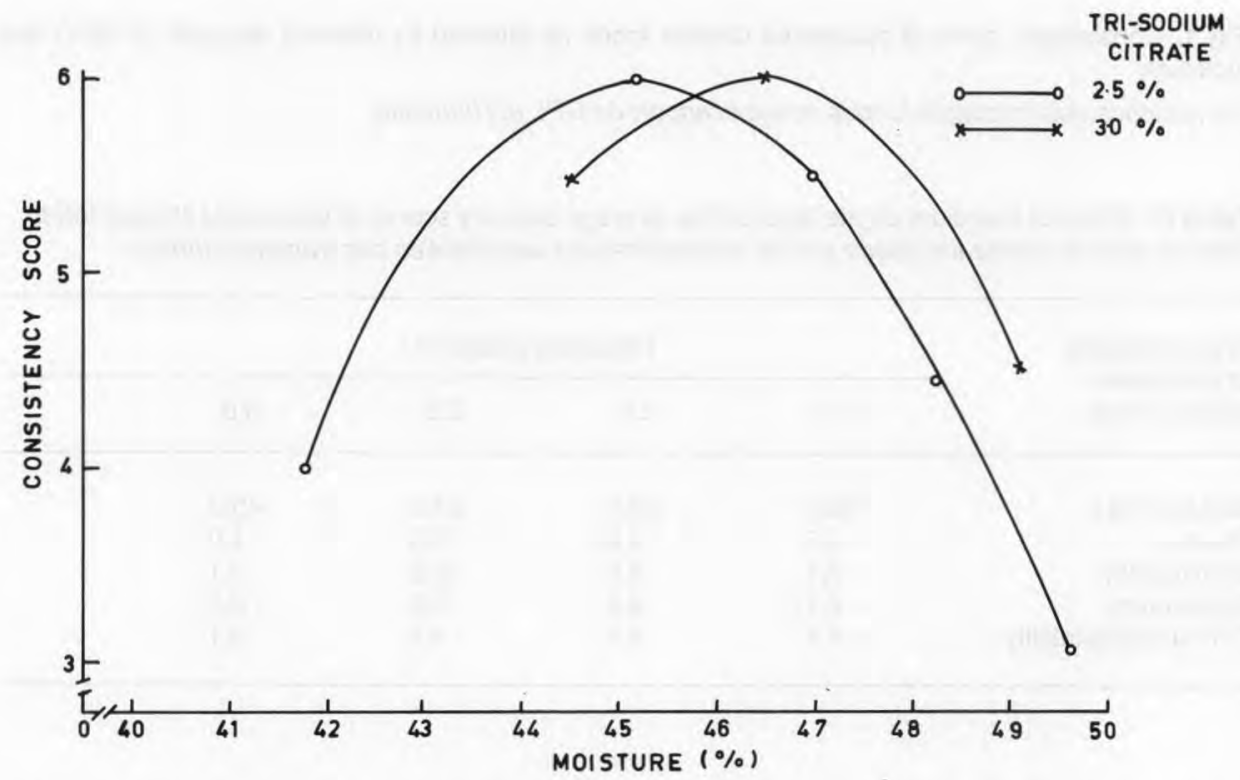

Fig 2. Consistency score of processed cheese foods as affected by different amounts of trisodium citrate and moisture.

Consistence des fromages fondus suivant la teneur en citrate trisodique et l'humidité. 
Table V. Comparative sensory scores of processed cheese food and commercial processed cheeses.

Comparaison des scores sensoriels du fromage fondu expérimental par rapport à ceux du commerce.

\begin{tabular}{llllllll}
\hline Characteristics & $\begin{array}{l}\text { Processed } \\
\text { cheese } \\
\text { food }\end{array}$ & $\begin{array}{l}\text { Control } \\
\text { processed } \\
\text { cheese }\end{array}$ & Amul & NDRI & $\begin{array}{l}\text { Kraft } \\
\text { sliced } \\
\text { Chester } \\
\text { (45\% fat } \\
\text { in DM) }\end{array}$ & $\begin{array}{l}\text { Kraft } \\
\text { cream } \\
\text { (50\% fat } \\
\text { in DM) }\end{array}$ & $\begin{array}{l}\text { Kraft } \\
\text { Valveta } \\
\text { (20\% fat } \\
\text { (in DM) }\end{array}$ \\
\hline Moisture (\%) & 45.2 & 41.3 & 45.4 & 41.8 & 48.4 & 50.8 & 59.4 \\
Flavour & 5.5 & 5.1 & 6.0 & 3.2 & 3.1 & 4.1 & 4.0 \\
Consistency & 5.8 & 5.4 & 6.0 & 4.1 & 4.1 & 5.2 & 4.2 \\
Appearance & 5.8 & 5.0 & 6.0 & 5.9 & 3.2 & 5.1 & 4.1 \\
Overall acceptability & 5.6 & 5.3 & 6.0 & 4.2 & 3.5 & 5.1 & 4.1 \\
\hline
\end{tabular}




\section{DISCUSSION}

\section{Effect of different emulsifying salts}

With the addition of WPC, the ratio of protein to fat in cheese becomes higher. In normal cheeses, where enough fat as well as water is present, one end of the protein will dissolve in the fat, the other end will dissolve in the water and a homogenous product will result. In the absence of sufficient fat, the excess or unemulsified protein separates into grainy or chalky water phase deposits (Shimp, 1985). One way to increase the available fat is to increase the degree of emulsification by adding emulsifying salts. This increases the total surface area of the fat without changing the amount of fat present.

Joha emulsifying salts have been used in the processed cheese industry in Europe with great success for over 60 years. At the moment, there are about 20 different Joha emulsifying salts available for different processed cheeses. However, in most factories only a few of these 20 different salts are used (Meyer, 1973). S-8 and $\mathrm{S}-10$ are such emulsifying salts (Prokopek, 1986; personal communication). It may be possible to obtain good quality cheese food with some combination of Joha salts, but the main difficulty with these salts is that their formulations are kept secret by the company. Failure of S-8 and S-10 Joha salts and combination of trisodium citrate and disodium phosphate emulsifying salts indicated that they could not increase the emulsifying power of fat sufficiently to take care of all the proteins in the system. The sandiness and chalkiness in cheese foods are probably due to the separation of unemulsified proteins.

In the Stephan Universal Machine, it is possible that the homogenizing effect pro- duced by high speed rotating knives may have increased the surface area of fat. This, combined with high moisture content, might have helped in the improved emulsificaton of proteins.

The better results obtained by using trisodium citrate as compared to other emulsifiers in the present study supports the earlier findings of a number of workers (Templeton and Sommer, 1930, 1932; Gupta et al, 1984) that sodium citrate was a better emulsifier than disodium phosphate. It is possible that the addition of this emulsifying salt increased the surface area of fat to a greater degree.

\section{Effect of different WPC}

With the increase in UF concentration of whey, protein, fat, ash and calcium content on a DM basis are increased in WPC (Hiddink et al, 1981; Gupta and Reuter, 1987). So, with the use of WPC with higher total solids, greater amounts of these constituents are incorporated into processed cheese foods. For a greater amount of protein and calcium, better emulsifying action is required in the processed cheese food systems for smooth consistency. Diafiltration of WPC further increases its protein and calcium content (Gupta and Reuter, 1987). The emulsifier has to retain calcium, solubilize protein and increase hydration and swelling to facilitate emulsification of fat during processing (Caric et al, 1985). As the amount of calcium phosphate is increased, the solubility of casein in water is decreased and so is its emulsifying capability. With higher UF concentration, which is necessary for greater incorporation of WPC solids in processed cheese foods without undue increase in moisture, increased protein content in WPC is inevitable. But the calcium content can be kept low with suitable preheating 
and UF conditions: (Gupta and Reuter, 1987; Hiddink et al, 1987) as in the case of WPC (26.1), which resulted in better quality processed cheese food.

\section{Effect of different moisture content}

Higher amount of WPC incorporation introduces more whey proteins in processed cheese foods and thus there is more intense emulsification in the system. This increased WPC addition appears to be responsible for the firmer body of processed cheese foods. Olson and Price (1961) also reported the increase in firmness of processed cheeses with the increase of nonfat solids to moisture in the system. In the present investigation, increased moisture content might be countering the firming effect of increased WPC in processed cheese foods.

\section{Effect of different levels of trisodium citrate}

A minimum amount of trisodium citrate emulsifier has to be added to processed cheese foods to increase the surface area of fat in order to emulsify all the available proteins for smooth consistency of the product. Excess addition of emulsifier should be avoided, as it will not only result in more intense emulsification, but also incur extra cost.

\section{Standardized processed cheese food}

Lesser amount of emulsifier should produce less intense emulsification and a softer body in processed cheese foods. Therefore, a lower moisture content at a low level of emulsifier addition should result in a desirable product consistency.
Comparative sensory quality of processed cheese food with commercial processed cheese

Whey proteins are highly nutritious and contain a greater amount of sulphurcontaining amino acids. During heat processing, these proteins become denatured and sulfhydryl groups are released which impart a heated or cooked flavour on heating (Parry, 1974). These flavours might enhance the flavour of processed cheese foods. Otherwise, the cheese flavour may have become diluted with the addition of non-cheese ingredients to the formulation. Processed cheeses in Germany are mostly of spreadable consistency, while Indian cheeses are mostly block type. Comparison of these cheese may not be very valid as preferences exist for all varieties of cheeses throughout the world. However, this comparison clearly shows the good quality of standardized processed cheese foods.

\section{ACKNOWLEDGMENTS}

The authors wish to thank SG Süffke, Managing Director of Asheberg Cheese Factory for providing the cheese whey. The assistance provided by $S$ Molzen during the chemical analysis is also gratefully acknowledged. Thanks are also due to DK Jain (NDRI, Karnal) for guidance and help in the statistical analysis of the data. The first author is also thankful to the Government of Germany for awarding him a post-doctoral fellowship under the German Academic Exchange Service programme.

\section{REFERENCES}

AOAC (1970) Official Methods of Analysis. Assoc Off Anal Chem, Washington, DC, 11th edn

Caric M, Gantar M, Kalab M (1985) Effects of emulsifying agents on the microstructure and 
other characteristics of processed cheese. A review. Food Microstruc 4, 297-312

Forsum E (1975) Use of a whey protein concentrate as a supplement to maize, rice and potatoes: a chemical and biological evaluation using growing rats. J Nutr 105, 147-153

Georgakis SA (1975) Concentration of whey protein by ultrafiltration and its use for processed cheese manufacture. Proc 20th World Vet Congr 1, 835-838

Gupta VK, Reuter H (1987) Studies on ultrafiltration of cheese whey for the manufacture of whey protein concentrates. Kiel Milchwirtsch Forschungber 39, 39-50

Gupta SK, Karahadian C, Lindsay RC (1984) Effects of emulsifier on textural and flavor properties of processed cheeses. J Dairy Sci 67, 764-778

Hiddink J, De Boer R, Nooy PFC (1981) Effect of various pre-treatments on the ultrafiltration of sweet cheese whey at about $55^{\circ} \mathrm{C}$. Milchwissenschaft 36, 657-663

Kairyukshtene IP, Zakharova NP, Shilovkiaya TP (1978) Uses of whey concentrates in the manufacture of processed cheese. 20th Int Dairy Congr, E 932-933
Kosikowski FV (1982) Cheese and Fermented Milk Foods Kosikowski FV and Associates, Brooktondale, NY, USA, 2nd edn revised, ch 391

Meyer A (1973) Processed Cheese Manufacture. Food Trade Press Ltd, London, UK

Olson NF, Price WV (19́61) Composition and bacterial growth as factors affecting the body of pasteurized processed cheese spread. J Dairy Sci 44, 1394-1404

Parry RM (1974) Milk coagulation and protein denaturation. In: Fundamentals of Dairy Chemistry (Webb BH, Johnson AH, Alford JA, eds) AVI Publ Co, Westport, 2nd edn

Shimp LA (1985) Processed cheese principles. Food Technol 39, 63-70

Snedecor GW, Cochran WG (1967) Statistical Methods. Oxford and IBM Publishing Co, Calcutta, India

Templeton HL, Sommer HH (1930) Some observations on processed cheese. J Dairy Sci 13, 203-220

Templeton HL, Sommer HH (1932) Factors affecting the body and texture of processed cheese. J Dairy Sci 15, 29-41 